\author{
G.R.Absattarov ${ }^{l}$, M.F. Shamilov ${ }^{l}$ \\ Kazakh Ablai Khan University of International Relations and World Languages \\ Almaty, Kazakhstan
}

\title{
CONSIDERING GENERAL LEGALAND TREATYBASES OF COOPERATION BETWEEN EUROPEAN UNION AND CENTRAL ASIA
}

\begin{abstract}
For almost three decades of partnership, Central Asia has become of a great strategic importance to the European Union due to the geographic location of the region between Asia and Europe and mutual common interests in cooperationissues. Based on this study on the evolution of the development of relations between the EU and the countries of the Central Asian region, carried through political, legal, economic and humanitarian mechanisms, the author gives an attempt to research the formation of the regulatory framework of this cooperation, based under legal acts, documents and agreements between parties.
\end{abstract}

Key words: European Union, Central Asia, legal bases, foreign policy, EU strategy.

\author{
Г.Р Әбсаттаров ${ }^{l}$ Шалилов М.Ф. ${ }^{1}$ \\ ${ }^{1}$ Абылайхан атындавы Қазақ халықаралық құатынастар және әлемдік тілдер университеті \\ Алмать, Қазақсстан
}

\section{ЕУРОПА ОДАҒЫ ЖӘНЕ ОРТАЛЫК АЗИЯ АРАСЫНДАҒЫ ҚҰҚЫҚТЫҚ ШАРТ НЕГІЗДЕРІНЕ ЖАЛПЫЛАМА ШОЛУ}

Орталық Азия шамамен үш онжылдық ішінде Еуропа мен Азия арасында географиялық тұрғыда орналасуына байланысты және ынтымақтастықтың түрлі мәселелері бойынша өзара ортақ мүдделерінің бар болуының негізінде Еуропалық Одақ үшін үлкен стратегиялық маңызға ие болды. Мақала ЕО мен Орталық Азия аймағы елдері арасындағы саяси, құқықтық, экономикалық және гуманитарлық аяны қолдану негізнде жүзеге асып жатқан қатынастардың даму эволюциясына арналып, сонымен қатар автор тараптар арасындағы құқықтық актілерге, құжаттарға және келісімдерге негізделген ынтымақтастықтың нормативтік - құқықтық негіздерінің қалыптасу ерекшелігін зерттейді.

Түйін сөздер: Еуропалық Одақ, Орталық Азия, құқықтық база, сыртқы саясат, ЕО стратегиясы.

$$
\text { Г.Р. Абсаттаров }{ }^{1} \text { Шамилов М.Ф. }{ }^{1}
$$

${ }^{1}$ Казахский университет международных отношений и мировых языков имени Абылай хана, Алматы, Казахстан

\section{ОБЩИЙ ОБЗОР ДОГОВОРНО-ПРАВОВЫХ ОСНОВ СОТРУДНИЧЕСТВА МЕЖДУ ЕВРОПЕЙСКИМ СОЮЗОМ И ЦЕНТРАЛЬНОЙ АЗИЕЙ}


За почти три десятилетия партнерства Центральная Азия приобрела большое стратегическое значение для Европейского Союза из-за географического расположения региона между Азией и Европой и взаимных общих интересов по разным вопросам сотрудничества. На основании данного исследования, посвященного эволюции развития отношений между ЕС и странами Центральноазиатского региона, что осуществлялось с помощью политических, правовых, экономических и гуманитарных механизмов, автор дает попытку изучения особенностей формирования нормативной базы этого сотрудничества, которое основано на правовых актах, документах и соглашениях между сторонами.

Ключевые слова: Европейский Союз, Центральная Азия, правовые основы, внешняя политика, стратегия ЕС.

\section{Introduction}

Since gaining independence, one of the priorities for the newly emerged states of Central Asia, who were interested in pursuing a well-balanced foreign policy, has been the establishment of mutually beneficial cooperation with global geopolitical players, including the European Union (EU) - one of the main centers of the modern international politics and economics.

In turn, the European integration process also initially sought to establish close cooperation with postSoviet countries in order to both expand political and economic ties and increase its influence on the development of these countries in regional dimension on long-term basis. As a result, nowadays, after almost three decades from the beginning of the establishment of the first contacts, relations between the Central Asian countries and the EU have acquired a complex, multifaceted character in the political, trade, economic, social and cultural fields, and are characterized by a high level of dynamism.

Several legal acts and treaties that established normative regulations for the future cooperation ensured the fundamentals of such basis. Considering the very first years of cooperation, experts [1] point out such objectives of the EU-CA partnership, as:(1) establishing a regular political dialogue between the parties at different levels, (2) the promotion of trade, investment and harmonious economic relations, (3) providing the basis for economic, social, financial and cultural cooperation, (4) support for the countries efforts to strengthen their democracies, with the development ofeconomy and complete the transition to a market economy. The further concern on legal framework would give better understanding of such strategic goals.

\section{Historical Background}

When considering the launch of European interests in the CA region in 1990-s, it should be mentioned that the process has gone along with the participation and inclusion of CA countries to different organizations and regional initiatives, and most significant, the Conference on Security and Cooperation in Europe (OSCE, from 1995). According to some reports, on average, the EU has funded around 70\% of all OSCE activities in Central Asia [2], which confirms increasing OSCE influence in the region. According to the historical view [3] on the EU-CA relations could be considered from four periodical milestones. Each period links with the install and development of new European strategy or foreign policy initiative towards Central Asia. The first one includes the end of XX century, the formation of the conceptual foundations for the regulatory framework of bilateral and multilateral cooperation between the parties. The official recognition of the political independence of the Central Asian countries, happened at the end of 1991 year,put a political foundation for the formation of bilateral and multilateral mutually beneficial ties. The legal basis for a unified approach of the EU foreign policy issues was formed with the adoption of the "Treaty on the European Union" in 1992, which structured the future life of European Union, including its internal and foreign policies. In particular, during the period from 1994 to 1996, the EU signed the "Partnership and Cooperation Agreement" (PCAs) with almost all Central Asian countries (see Table 1).

The entry into force in July 1999 of the PCAs was the starting point for the second stage of development of cooperation between the EU and the countries of Central Asia. One of the practical mechanisms of cooperation was the Technical Assistance for the Commonwealth of Independent States (TACIS) program. The main goal of the Program was "to ensure the transition to a market economy and strengthen democracy and the rule of law in the states of the region". It has included several projects, and one of the most important projects in the field of transport communications was TRACECA (Transport Corridor Europe Caucasus Asia) with a plan for the creation of a communication system connecting the two regions through the Black Sea, the Caucasus and the Caspian Sea. The third stage in the development of relations between the EU and Central Asian countries defined by special geographic importance of the region in connection with the security issues 
in Afghanistan and the region itself. The geopolitical situation in the world has changed dramatically after the 9/11 events in the United States. The problem of ensuring security from external threats has become the main issue on the agenda of the entire international community. Europeans recognized that only a peaceful, economically prosperous, democratic Central Asia could become their reliable partner towards ensuring stability and security in the region. Along with this, one of the priority areas of development was the improvement of the educational systems of Central Asian states based on European standards. This reconsideration of EU initiatives towards Central Asia led to the new document by the European Parliament and the European Council, approved in October 2006, namely a joint regulation on the adoption of the "European Instrument of Neighborhood and Partnership" [4], which addressed issues of cooperation not only with the closest neighboring states, but also with the countries of the Central Asian region. The Neighborhood Tool included a number of conceptual documents on cooperation with individual states and regions. The adoption of the EU Strategy (2007-2013) towards Central Asia, along with two indicative programs, has opened up new opportunities for cooperation. Here the problem emerged, which consisted in insufficient connection of the Strategic Document and the Indicative Programs with the EU Action Plans. During the implementation of the Strategy, it was supposed to overcome this issue.

The fourth stage in the development of relations between the EU and Central Asia began in 2015 with the adoption of the updated European Union Strategy for Central Asia for 2017-2020, which eventually ended up with the New EU strategy towards Central Asia, presented in Bishkek, 2019 summer. Unlike previous strategies, the renewed EU Central Asia strategy provides windows for the implementation of modern projects that have substantially large volumes of both short and long term nature.

\section{Legal and conceptual framework of EU foreign policy towards Central Asia}

The EU strategy towards Central Asia has been an important area of interest in different academic and scientific circles since the beginning of the 21st century. However, scientists conclude [5] that Central Asian region is still less examined part of EU Neighborhood policy.

Several key regulations points out EU foreign policy strategy in Central Asia, including (1) Title V of the Treaty on European Union (TEU): 'external action'; (2) Articles 206-207 (trade) and Articles 216-219 (international agreements) of the Treaty on the Functioning of the European Union (TFEU); (3) Partnership and Cooperation Agreements (PCAs) covering bilateral relations, with the exception of Turkmenistan for which an interim trade agreement is in place. The new Enhanced PCA (EPCA) were launched then, with Kazakhstan is being applied provisionally pending ratification by all EU Member States. The EPCA with Kyrgyzstan was installed in July 2019 and negotiations with Uzbekistan are underway. Tajikistan has expressed its interest in an enhanced agreement too (see Table 1).

It is also important to strengthen the role and activities of European Parliament towards the partnership strategy [6]. Generally, we divide them on three categories, including: (1) positions adopted (resolutions) towards actions and strategies; (2) inter-parliamentary cooperation; and (3) election observation and democracy promotion.

\section{Treaties and agreements foundations of continuous partnership}

The EU cooperates historically with Central Asian countries at the bilateral and multilateral (regional) levels. As for the first pillow, the EU is in a relationship with Central Asia based on the Partnership and Cooperation Agreements (PCAs and EPCAs), a basic agreement signed first individually with each country in 1995. It entered into force almost simultaneously in all CA republics on July 1, 1999. The European Union's basic agreement essentially expresses the nature of this entity. So far, for the EU, the trade and economic component is mainly important and political conditions traditionally drawn up after another document. Experts argue that trade and economic motivation determines the key areas and areas of interaction, remains the essence of the concept and strategy of promoting the European Union in Central Asia [7]. The status and chronology of PCA conclusion can be seen in Table 1 below [8]:

Table 1. EU-CA Partnership and Cooperation Agreements

\begin{tabular}{|l|l|l|l|}
\hline Country & PCA & EPCA & Current status \\
\hline
\end{tabular}




\begin{tabular}{|c|c|c|c|}
\hline Kazakhstan & In force since 1999 & $\begin{array}{l}\text { Signed in } 2015 \text {, not yet ratified } \\
\text { PCA; }\end{array}$ & $\begin{array}{l}\text { pending ratification, some } \\
\text { provisions of EPCA } \\
\text { provisionally applied }\end{array}$ \\
\hline Kyrgyzstan & In force since 1999 & $\begin{array}{l}\text { Negotiations launched December } \\
2017\end{array}$ & PCA \\
\hline Tajikistan & In force since 2010 & $\begin{array}{l}\text { Tajik request for negotiations in } \\
\text { November 2018, not yet launched }\end{array}$ & PCA \\
\hline Turkmenistan & $\begin{array}{l}\text { Signed in } 1998 \text { but } \\
\text { not yet ratified }\end{array}$ & & $\begin{array}{l}\text { Interim trade agreement } \\
\text { pending ratification of PCA }\end{array}$ \\
\hline Uzbekistan & In force since 1999 & $\begin{array}{l}\text { Negotiations launched in November } \\
2018\end{array}$ & PCA \\
\hline
\end{tabular}

However, Central Asia received a clearer role on the foreign policy radar of Europe only after the development of the EU Strategy for Central Asia in 2007. The EU opened its representative offices in Central Asia, launched a number of projects, increased funding and created several formats for bilateral and regional cooperation. As for the second pillow, the EU Strategy for a New Partnership with Central Asia was adopted by the Council of Europe on June 21-22, 2007, confirming the growing importance of Central Asia in the field of EU interests in terms of security, stability, management and diversification of energy. The strategy provided the general structure of EU relations with Central Asia and was based on previous achievements in building relations with Central Asian countries, EU assistance programs and other initiatives, undertaken by the European Union. EU priorities for cooperation with the region as a whole include cooperation in the field of human rights, the rule of law, good governance and democracy, education, economic development, trade and investment, energy and transport, environmental policy, common threats and challenges, and intercultural dialogue.

\section{EU-CA strategic documents as legal framework of previous partnership included [9]:}

- European Union and Central Asia: New Partnership Strategy (2007)

- Joint preliminary report on the implementation of the EU Strategy for Central Asia (2012)

- Conclusions of the Council on the implementation of the EU Strategy for Central Asia (2015)

Finally, as for the third pillow and current framework for EU foreign policy towards Central Asia, recently the new strategy "The European Union and Central Asia: New Opportunities for a Stronger Partnership" was presented. The new Strategy will help identify cooperation programs in the region, as suggested. "Central Asia has always been a key region: because of its history, because of its culture and because of its role in uniting East and West. Today, it is gaining more and more strategic importance against the background of positive internal and regional dynamics, as well as growing global challenges that require strengthening partnerships", the words of the head of the European diplomacy Federica Mogherini underline the place of Central Asia within EU's regional policy, according to the official communiqué by the European Commission [10].

The new EU Central Asia Strategy was endorsed by the Council in June 2019. The earlier version of the strategy from 2007 has been updated to focus on resilience (covering areas such as human rights, border security, environment), prosperity (with a strong accent on connectivity), as well as regional cooperation. It also puts a greater emphasis on Central Asia-Afghanistan relations. The importance of a regional approach and of regional cooperation is also stressed by the EU-Central Asia Ministerial Meetings, the last one (15th) having taken place in July 2019 in Bishkek.

\section{Conclusion}

To sum up, after analysis of general and fundamental legal framework between EU and Central Asia, we can argue that nowadays both the Central Asia countries and the European Union are deeply interested in the further development and deepening of both political and trade-economic relations, but not limited. At the same 
time, it is obvious that the current Partnership and Cooperation Agreement between CA countries and the EU is no longer up to date and requires fundamental changes. We clearly see the understanding of that from EU officials, since the New EU strategy towards Central Asia (2019) became one of the step towards new level of relations and partnership.

\section{References:}

1. KembaevZH.M. Pravovye osnovy partnerstva mezhdu Respublikoj Kazahstan i Evropejskim Soyuzom // YUrist. 2013. № 7. C. 44-49.

2. Paramonov V.V., Strokov A.V., Abduganieva Z.A. Vliyanie Evropejskogo Soyuza na Central'-nuyu Aziyu: obzor, analiz i prognoz. - Almaty: Fond imeni Fridriha Eberta, 2017 god. - 117 s.

3. Tursunmuratov T.M. Politiko-pravovye osnovy vneshnepoliticheskoj deyatel'nosti Evropejskogo soyuza v regione Central'noj Azii // Vestnik Volgogradskogo gosudarstvennogo universiteta. Seriya 4, Istoriya. Regionovedenie. Mezhdunarodnye otnosheniya. - 2017. - T. 22, №4. - S. 162-168.

4. Regulation №1638/2006 of th eEuropean Parliament and of the Council of 24 October 2006, layingdowngeneralprovisionsestablishing a European Neighbourhood and Partnership Instrument // Official Journal of the EU (L310), 19.11.2006 (available online).

5. Raev D.S., Kasenov F.ZH. Dialog Kazahstan - Evropejskij Soyuz: polifoniya sotrudnichestva//Izvestiya KazUMOiMYA imeni Abylaj hana. Seriya «Mezhdunarodnye otnosheniya i Regionovedenie». - №3(21). 2015. - S.3-9.

6. European Parliament. Sheets on the European Union. Central Asia. URL: [https://www.europarl.europa.eu/factsheets/en/sheet/178/central-asia]

7. CHebotaryov A.E., Gubajdullina M.SH. Strategiya Evropejskogo Soyuza v Central'noj Azii na 20072013 gg.: predvaritel'nye itogi: Monografiya / Pod obshch. red. A.E. CHebotaryova. - Almaty: Centr aktual'nyh issledovanij "Al'ternativa»; Centr germanskih issledovanij KazNU im. al'-Farabi; Fond im. FridrihaEbertavKazahstane, 2013. - 184 s.

8. Russell M. The EU's new Central Asia strategy. European Parliamentary Research Service. Author: PE 633.162 - January 2019

9. Council of the European Union (official page). URL: [https://www.consilium.europa.eu/en/press/pressreleases/2019/06/17/central-asia-council-adopts-a-new-eu-strategy-for-the-region/\#]. Retrieved 22.11.2019

10. Official Press release,15 May 2019, European Commission, Brussels. URL: [https://ec.europa.eu/commission/presscorner/detail/en/IP_19_2494]. Retrieved 23.11.2019. 